\title{
Berat Organ Non Karkas Ayam Broiler Setelah Disuplementasi Dl-Methionine dalam Pakan
}

\section{Selviana Suni ${ }^{\mathrm{a}}$, Charles Venerius Lisnahan ${ }^{\mathrm{b}}$, Agustinus Agung Dethan ${ }^{\mathrm{c}}$}

${ }^{a}$ Fakultas Pertanian, Universitas Timor, Kefamenanu, TTU - NTT, Indonesia, email: selvisuni6@gmail.com

${ }^{b}$ Fakultas Pertanian, Universitas Timor, Kefamenanu, TTU - NTT, Indonesia, email: charleslisnahan@yahoo.co.id

${ }^{c}$ Fakultas Pertanian, Universitas Timor, Kefamenanu, TTU - NTT, Indonesia, email: dethanagung15@gmail.com

\section{Article Info}

\section{Article history:}

Received 01 Juli 2020

Received in revised form 13 Desember 2020

Accepted 10 Januari 2020

\section{DOI:}

https://doi.org/10.32938/ja.v6i1.1068

\section{Keywords:}

Ayam broiler

Dl-methionine

Pakan komersial

Organ non karkas

\section{Abstrak}

Tujuan penelitian ini adalah untuk mengetahui pengaruh suplementasi dl-methionine dalam pakan terhadap kinerja organ non karkas ayam broiler. Penelitian ini dilaksanakan di Kandang Program Studi Peternakan, Fakultas Pertanian Universitas Timor, Kelurahan Sasi, Kecamatan Kota Kefamenanu, Kabupaten Timor Tengah Utara. Penelitian ini berlangsung selama 39 (1 masa produksi). Penelitian ini menggunakan 80 ekor ternak ayam broiler berumur 1 hari atau Day Old Chick (DOC) Strain CP 707. Metode yang digunakan dalam penelitian ini adalah metode eksperimen dengan Rancangan Acak Lengkap (RAL) pola searah, terdiri dari 4 perlakuan dan 4 ulangan. Perlakuan yang diuji adalah: $\mathrm{T}_{0}$ (pakan control), $\mathrm{T}_{1}\left(\mathrm{~T}_{0}+\right.$ dl-methionine $\left.0,30 \%\right), \mathrm{T}_{2}\left(\mathrm{~T}_{0}+\right.$ dl-methionine $\left.0,50 \%\right)$, dan $\mathrm{T}_{3}\left(\mathrm{~T}_{0}+d l\right.$ methionine $0,70 \%$ ). Variabel yang diamati adalah persentase berat non karkas, persentase darah, persentase bulu, persentase berat potong, persentase berat kepala, persentase berat leher, dan persentase lemak abdominal ayam broiler. Hasil penelitian menunjukkan bahwa perlakuan berpengaruh nyata terhadap berat dan persentase darah, bulu, berat potong dan non karkas ayam broiler $(\mathrm{P}<0,05)$ sedangkan berat dan persentase kepala, leher, serta lemak abdominal berpengaruh tidak nyata. Rata-rata berat kepala T0:48,58 $\pm 2,29$;

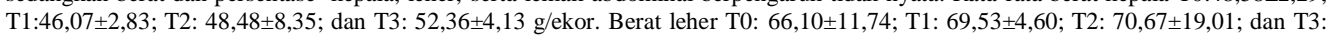

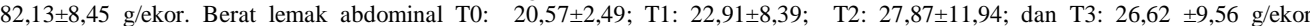
Disimpulkan bahwa pakan komersial yang disuplementasi dengan dl-methionine sebesar $0,70 \%$ meningkatkan pertumbuhan dan perkembangan non karkas berat bulu, berat darah, berat kepala dan leher, lemak abdominal, serta berat potong ayam broiler.

\section{Pendahuluan}

Protein hewani yang dibutuhkan masyarakat dapat dipenuhi dari produk peternakan, salah satunya ayam broiler. Ayam broiler merupakan jenis ternak unggas yang memiliki laju pertumbuhan yang sangat cepat dengan lama pemeliharaan yang relatif singkat serta memberikan kontribusi besar dalam memenuhi kebutuhan protein asal hewani bagi masyarakat. Selain itu, pemeliharaan ayam broiler dapat dilakukan di tempat yang sederhana. Kelebihan lain dari ayam broiler adalah memiliki tingkat penyesuaian yang cepat dan efektif dalam mentransformasikan pakan menjadi daging yang berkualitas (Ensminger et al., 2004).

Pemeliharaan ayam broiler perlu memperhatikan faktor-faktor yan mempengaruhi laju pertumbuhan agar ternak ayam broiler dapat bertumbuh cepat dalam waktu yang relatif singkat. Salah satu faktor yang berpengaruh yaitu pakan yang berkualitas. Pakan merupakan sumber energi, protein, mineral, dan vitamin agar ternak dapat melangsungkan hidupnya. Pakan merupakan hal dasar yang harus diperhatikan karena merupakan kebutuhan pokok yang berpengaruh terhadap pertambahan bobot badan. Kualitas pakan yang baik akan menghasilkan pertumbuhan dan perkembangan ayam broile maksimal, begitu juga dengan kualitas pakan yang rendah akan menghasilkan pertumbuhan dan perkembangan yang buruk bagi ternak tersebut. Kemampuan ternak dalam mencerna bahan pakan ditandai dengan efisiensi suatu bahan pakan yang dapat dicerna atau diserap oleh saluran pencernaan. Pakan yang berkualitas adalah pakan yang mudah dicerna dan diserap ternak. Pakan in memiliki kandungan energi, protein, mineral, dan vitamin yang sesuai dengan kebutuhan ternak. Sesuai dengan NRC (1994), kebutuhan energ termetabolisme adalah $3000 \mathrm{kkal} / \mathrm{kg}$, protein kasar 21-23\%, lemak kasar lebih dari 3\%, dan serat kasar maksimum 5\%.

Selain energi termetabolisme dan protein kasar, perlu diperhatikan kebutuhan mikronutrien seperti asam amino esensial. Asam amino esensial merupakan jenis asam amino yang tidak dapat diproduksi di dalam tubuh ternak sehingga dalam pemberian pakan pada ayam broiler perlu disuplementasi dengan asam amino esensial untuk meningkatkan performa dari ayam broiler yang dipelihara.

Setiap jenis asam amino memiliki peranannya masing-masing dalam metabolisme dan fungsi fisiologis seperti pembentukan daging, penurunan kadar lemak daging dan kolestrol, serta berfungsi sebagai peningkat performa ternak unggas. Pakan ayam broiler di daerah tropis yang berbasis jagung dan bungkil kedelai bisasanya diefisienkan menggunakan asam amino methionine dan lysine. Asam amino yang terkandung dalam methionine sangat istimewa Umumnya suplementasi diberikan dalam bentuk kering atau cair untuk meningkatkan kinerja unggas. Ketersediaan dl-methionine dalam makanan mempengaruhi komposisi asam amino protein tubuh (Conde-Aguilera et al. 2011)

Penelitian terdahulu telah menyatakan bahwa tampilan ayam broile bervariasi (Amerah et al., 2013; Nofal et al., 2015; Sakomura et al., 2013). Methionine merupakan asam amino esensial kritis yang mengandung sulfur dan diperlukan ternak untuk sistem metabolisme. Peran dl-methionine bagi unggas adalah sebagai suplai pembentuk kholin, bulu, penghilang racun tubuh, serta pembentukan taurin dalam menyusun garam empedu (Anggorodi, 1995). Dlmethionine adalah asam amino yang sangat dibutuhkan ternak unggas untuk pertumbuhan dan perkembangan.

\section{Metode}

Penelitian ini dilaksanakan di kandang ayam broiler milik Program Stud Peternakan, Fakultas Pertanian, Universitas Timor, Kefamenanu. Penelitian in telah dilaksanakan selama 39 hari (1 masa produksi). Ternak yang digunakan dalam penelitian ini adalah ayam broiler berjumlah 80 ekor berumur 1 hari (day old chick) strain CP 707. Ayam broiler dipelihara secara intensif dengan sistem litter. Jenis pakan yang digunakan dalam penelitian ini yaitu pakan ayam broiler $\mathrm{BR}_{1}$ produksi PT. Wonokoyo Jaya Surabaya dan dl-methionine. Bahan lain yang digunakan adalah air minum.

Tabel 1. Komposisi ransum BR1.

\begin{tabular}{lc}
\hline Nutrien & Kandungan* \\
\hline Air $(\%)$ & 12,0 \\
Energi termetabolisme (kkal/kg) & 3200 \\
Protein kasar (\%) & 22,0 \\
Lemak kasar (\%) & 5,0 \\
Serat kasar (\%) & 5,0 \\
Abu (\%) & 7,5 \\
Kalsium (\%) & 0,9 \\
Fosfor (\%) & 0,6 \\
\hline
\end{tabular}

Fosfor $(\%)$

Sumber: PT. Charoen Pokphand, 2014. Keterangan: *tersusun dari jagung, katul, pollard, corn gluten meal (CGM), distillers dried grains with solubles (DDGS), bungkil keledai, tepung jagung, tepung tulang, crude palm oil (CPO), canola, vitamin, dan mineral.

Kandang yang digunakan dalam penelitian ini yaitu kandang litter dengan ukuran $3,5 \times 7,0 \mathrm{~m}$. Di dalam kandang tersebut dibuat 16 unit kandang berukuran $60 \mathrm{~cm} \times 70 \mathrm{~cm} \times 60 \mathrm{~cm}$. Setiap unit kandang terisi 5 dengan perlakuan $\mathrm{T}_{0}$ (pakan kontrol tanpa Dl-methionine), $\mathrm{T}_{1}$ (pakan dengan suplementasi Dl-methionine sebanyak 0,30\%), $\mathrm{T}_{2}$ (pakan dengan suplementasi Dl-methionine sebanyak 0,50\%) $\mathrm{T}_{3}$ (pakan dengan suplementasi Dl-methionine sebanyak 0,70\%). Komposisi pakan perlakuan tersaji pada Tabel 1

\subsection{Variabel Penelitian}

\subsubsection{Alat dan Bahan}

Variabel yang diteliti dalam penelitian ini adalah berat non karkas, berat darah, berat bulu, berat potong, berat kepala, berat leher, dan lemak abdominal ayam broiler.

\subsection{Analisis Data}

Data dianalisis menggunakan analisis varians dan dilanjutkan dengan uji Duncan dengan bantuan software Statistical Product and Service Solution (SPSS) Versi 21.

\section{Hasil dan Pembahasan}

\subsection{Berat dan Persentase Berat Potong Ayam Broiler}

Rata-rata berat dan persentase berat potong ayam broiler tersaji pada Tabel 2. Rata-rata berat potong tertingi terdapat pada $\mathrm{T}_{3}$ yaitu $2123,00 \pm 26,42$ g/ekor. Selanjutnya diikuti perlakuan $\mathrm{T}_{1} \quad\left(2025,75 \pm 42,37\right.$ g/ekor, $\mathrm{T}_{2}$ $\left(2006,00 \pm 54,6\right.$ g/ekor), dan terendah pada perlakuan $\mathrm{T}_{0}(1814,26 \pm 56,74$ g/ekor). Analisis sidik ragam menunjukkan bahwa perlakuan berpengaruh nyata terhadap berat badan potong ayam broiler $(\mathrm{P}<0,05)$. Rata-rata persentase berat potong tertinggi adalah pada perlakuan $\mathrm{T}_{1}(97,53 \pm 1,16 \%)$, diikuti $\mathrm{T}_{0}$ $(96,76 \pm 0,25 \%), \quad \mathrm{T}_{2} \quad(96,49 \pm 0,10 \%), \quad$ dan terendah $\mathrm{T}_{3} \quad(96,48 \pm 0,17 \%)$ Suplementasi $0,30 \%$ dl-methionine $\left(\mathrm{T}_{1}\right)$ dalam pakan meningkatkan $11,66 \%$ berat potong dibandingkan dengan perlakuan $\mathrm{T}_{0}$ (tanpa suplementasi $d l$ methionine). Apabila dinaikkan menjadi $0,50 \%$ dl-methionine $\left(\mathrm{T}_{2}\right)$, belum terjadi perubahan bobot potong dibandingakan perlakuan $\mathrm{T}_{1}$. Jika ditingkatkan menjadi $0,70 \%$ dl-methionine dalam pakan, berat potong masih meningkat $4,80 \%$. Asam amino methionine dapat meningkatkan berat potong karena berfungsi untuk sintesis protein dan sebagai donor gugus metil. Berat potong merupakan berat yang diperoleh pada akhir masa penelitian, data berat potong diperoleh melalui penimbangan dimana sebelumnya ternak dipuasakan selama 12 jam dan disembelih. Bobot potong dipengaruhi oleh pertambahan bobo badan dan umur ternak, sedangkan pertambahan bobot badan dipengaruhi oleh 
asupan nutrien (Soeparno, 2005). Faktor lain yang berpengaruh terhadap perbedaan bobot potong tersebut salah satunya adalah suhu. Suhu yang baik untuk pertumbuhan ayam broiler adalah sebesar $19-27^{\circ} \mathrm{C}$ (Amrullah, 2004). Pada kondisi yang cukup panas, ayam broiler akan mengurangi konsumsi pakannya.

Tabel 2. Rata-rata kinerja ayam broiler (g/ekor).

\begin{tabular}{|c|c|c|c|c|}
\hline \multirow{2}{*}{ Parameter } & \multicolumn{4}{|c|}{ Perlakuan } \\
\hline & $\mathrm{T}_{0}$ & $\mathrm{~T}_{1}$ & $\mathrm{~T}_{2}$ & $\mathrm{~T}_{3}$ \\
\hline $\begin{array}{l}\text { Berat Potong } \\
\text { (g/ekor) }\end{array}$ & $1814,25 \pm 56,74^{\mathrm{c}}$ & $2025,75 \pm 42,37^{\mathrm{b}}$ & $2006,00 \pm 54,67^{\mathrm{b}}$ & $2123,00 \pm 26,42$ \\
\hline Persentase & & & & \\
\hline $\begin{array}{l}\text { Berat Potong } \\
\text { (\%/ekor) }\end{array}$ & $96,76 \pm 0,25^{\mathrm{ab}}$ & $97,53 \pm 1,16^{\mathrm{a}}$ & $96,49 \pm 0,10^{\mathrm{b}}$ & $96,48 \pm 0,17^{b}$ \\
\hline $\begin{array}{l}\text { Berat Non } \\
\text { Karkas }\end{array}$ & & & & \\
\hline $\begin{array}{l}\text { (g/ekor) } \\
\text { Persentase }\end{array}$ & $587,60 \pm 25,62^{\mathrm{b}}$ & $619,44 \pm 19,89^{\mathrm{ab}}$ & $594,59 \pm 13,51^{\mathrm{b}}$ & $633,18 \pm 27,97$ \\
\hline Berat Non & & & & \\
\hline $\begin{array}{l}\text { Karkas } \\
\text { (\%/ekor) }\end{array}$ & $31,34 \pm 0,25^{\mathrm{a}}$ & $29,82 \pm 1,16^{\mathrm{b}}$ & $28,60 \pm 0,10^{\mathrm{b}}$ & $28,77 \pm 0,17^{\mathrm{b}}$ \\
\hline $\begin{array}{l}\text { Berat Darah } \\
\text { (g/ekor) }\end{array}$ & $60,75 \pm 4,35^{\mathrm{b}}$ & $62,50 \pm 5,26^{\mathrm{b}}$ & $73,00 \pm 3,16^{\mathrm{a}}$ & $77,50 \pm 4,04^{\mathrm{a}}$ \\
\hline Persentase & & & & \\
\hline $\begin{array}{l}\text { Berat Darah } \\
\text { (\%/ekor) }\end{array}$ & $3,24 \pm 0,25^{\mathrm{ab}}$ & $3,01 \pm 0,27^{b}$ & $3,51 \pm 0.10^{\mathrm{a}}$ & $3,52 \pm 0,17^{\mathrm{a}}$ \\
\hline $\begin{array}{l}\text { Berat Bulu } \\
\text { (g/ekor) }\end{array}$ & $64,00 \pm 2,71^{\mathrm{ab}}$ & $75,00 \pm 13,14^{a}$ & $68,25 \pm 8,30^{\mathrm{ab}}$ & $58,50 \pm 5,97^{\mathrm{b}}$ \\
\hline Persentase & & & & \\
\hline $\begin{array}{l}\text { Berat Bulu } \\
\text { (\%/ekor) }\end{array}$ & $3,42 \pm 0,21^{\mathrm{a}}$ & $3,60 \pm 0,54^{\mathrm{a}}$ & $32,8 \pm 0,39^{\mathrm{a}}$ & $2,66 \pm 0,26^{\mathrm{b}}$ \\
\hline $\begin{array}{l}\text { Berat Kepala } \\
\text { (g/ekor) }\end{array}$ & $48,58 \pm 2,29$ & $46,07 \pm 2,83$ & $48,48 \pm 8,35$ & $52,36 \pm 4,13$ \\
\hline Persentase & & & & \\
\hline $\begin{array}{l}\text { Berat Kepala } \\
\text { (\%/ekor) }\end{array}$ & $2,59 \pm 0,11$ & $2,22 \pm 0,15$ & $2,33 \pm 0,34$ & $2,38 \pm 0,16$ \\
\hline
\end{tabular}

\subsection{Berat dan Persentase Berat Non Karkas Ayam Broiler}

Rata-rata berat dan persentase berat non karkas ayam broiler tersaji pada Tabel 2. Rata-rata berat non karkas tertinggi adalah perlakuan $T_{3}$ yaitu $633,18 \pm 27,97$ g/ekor diikuti $\mathrm{T}_{1}(619,44 \pm 19,89$ g/ekor $), \mathrm{T}_{2}(594,59 \pm 13,51$ g/ekor), dan terendah pada $\mathrm{T}_{0}(587,60 \pm 25,62 \mathrm{~g} / \mathrm{ekor})$. Analisis sidik ragam menunjukkan bahwa perlakuan berpengaruh nyata terhadap berat non karkas ayam broiler $(0<0,5)$. Pada Tabel 4 , rata-rata persentase berat non karkas tertinggi adalah pada perlakuan $\mathrm{T}_{0}(31,34 \pm 1,11 \%)$, diikuti $\mathrm{T}_{1}(29,82 \pm 0,33 \%), \mathrm{T}_{3}$ $(28,77 \pm 0,94 \%)$, dan terendah pada $\mathrm{T}_{2}(28,61 \pm 0,33 \%)$. Suplementasi $d l$ methionine $0,30 \%$ dalam pakan meningkatkan $5,14 \%$ berat non karkas ayam broiler dibandingkan dengan perlakuan $\mathrm{T}_{0}$. Apabila ditingkatkan menjadi $0,50 \%\left(\mathrm{~T}_{2}\right)$, berat non karkas belum signifikan jika dibandingkan dengan perlakuan $\mathrm{T}_{1}$. Pada $\mathrm{T}_{3}$, dengan ditingkatkan level suplementasi dl-methionine menjadi $70 \%$; berat nonkarkas meningkat sebesar $6,10 \%$ dibandingkan dengan $\mathrm{T}_{2}$. Analisis statistik terhadap persentase berat non karkas menunjukkan perbedaan nyata pada setiap perlakuan. Persentase berat non karkas tertinggi pada perlakuan $\mathrm{T}_{0}$. Terdapat kecenderungan persentase berat non karkas lebih tinggi pada perlakuan tanpa suplementasi dl-methionine dibandingkan dengan yang mendapatkan suplementasi dl-methionine. Hal ini memberikan indikasi bahwa pakan yang mempunyai nutrien seimbang, mengandung kualitas pakan yang baik dalam menghasilkan berat non karkas yang lebih tinggi. Beberapa faktor yang mempengaruhinya adalah umur, jenis, manajemen, lingkungan, dan pakan. Khoiruddin (2009) menyatakan bahwa bobot non karkas ayam broiler berkisar 465,26-473,34 g, sedangkan Alfi (2009) menyatakan bahwa bobot non karkas ayam broiler pada umur 35 hari berkisar antara 417,00-483,75 g. Semakin tinggi bobot karkas maka akan semakin rendah bobot non karkasnya.

\subsection{Berat dan Persentase Berat Darah Ayam Broiler}

Rata-rata berat dan persentase berat darah ayam broiler tersaji pada Tabel 2. Rata-rata berat darah tertinggi adalah pada perlakuan $\mathrm{T}_{3}(77,50 \pm 4,04$ g/ekor) diikuti $\mathrm{T}_{2}\left(73,00 \pm 3,16\right.$ g/ekor), $\mathrm{T}_{1}(62,50 \pm 5,26 \mathrm{~g} / \mathrm{ekor})$, dan terendah pada $\mathrm{T}_{0}(60,75 \pm 4,35 \mathrm{~g}$ /ekor). Rata-rata persentase berat darah tertinggi adalah pada perlakuan $\mathrm{T}_{3}(3,53 \pm 0,17 \%$ /ekor $)$, diikuti $\mathrm{T}_{2}(3,51 \pm 0,10 \% / \mathrm{ekor}), \mathrm{T}_{0}$ $\left(3,24 \pm 0,25 \%\right.$ /ekor), dan terendah pada $\mathrm{T}_{1}(3,01 \pm 0,27 \%$ /ekor $)$. Berat darah pada perlakuan dengan suplementasi dl-methionine lebih baik karena dipengaruhi oleh nutrien yang lebih seimbang. Berat darah berkorelasi dengan berat badan; semakin tinggi bobot badan, berat darah juga semakin meningkat. Dl-methionine berfungsi untuk mensintesis protein dan sebagai donor gugus metil dalam pembentukan protein tubuh atau protein pada setiap jaringan tubuh dan meningkatkan pertumbuhan. Soepraptini et al. (2011) menyatakan bahwa darah merupakan bagian dalam sistem sirkulasi tubuh; berfungsi sebagai media transportasi dari berbagai macam zat yang dibutuhkan oleh tubuh. Darah mempunyai unsur seluler terdiri atas eritrosit, leukosit, dan keping darah (Yanti et al., 2013). Peningkatan persentase darah ayam broiler dipengaruhi oleh faktor umur dan kandungan nutrien yang terdapat dalam pakan. Hal ini sesuai dengan pendapat Kusnadi (2012), bahwa bobot badan dan pakan yang dikonsumsi menyuplai asupan gizi tubuh, sehingga berguna dalam pembentukan sel darah merah.

\subsection{Berat dan Persentase Berat Bulu Ayam Broiler}

Rata-rata berat dan persentase bulu ayam broiler tersaji pada Tabel 2 . Rata-rata berat bulu tertinggi adalah pada perlakuan $\mathrm{T}_{1}(75,00 \pm 13,14$ g/ekor), diikuti $\mathrm{T}_{2}\left(68,25 \pm 8,30 \mathrm{~g}\right.$ /ekor), $\mathrm{T}_{0}(64 ., 00 \pm 2,71 \mathrm{~g} / \mathrm{ekor})$, dan terendah pada $\mathrm{T}_{3}$ $(58,50 \pm 5,97 \mathrm{~g}$ /ekor). Analisis sidik ragam menunjukkan bahwa perlakuan berpengaruh nyata terhadap berat bulu ayam broiler $(\mathrm{P}<0,05)$. Pada Tabel 8 , rata-rata persentase berat bulu tertinggi adalah pada perlakuan $T_{1}$ $(3,60 \pm 0,54 \%)$, diikuti $\mathrm{T}_{0}(3,42 \pm 0,21 \%), \mathrm{T}_{2}(3,28 \pm 0,39 \%)$, dan terendah pada $\mathrm{T}_{3}$ $(2,66 \pm 0,26 \%)$. Berat bulu tertinggi pada perlakuan dengan level dl-methionine 0,30 dan $0,50 \%$, sedangkan pada level selanjutnya menurunkan persentase berat bulu. Lesson dan Summer (1997) menyatakan bahwa pertumbuhan bulu dapat terhambat karena terhentinya siklus dalam pemberian makanan. Menurut Biquil et al. (1992), asam amino methionine dan lysine berperan dalam pembentukan jaringan tubuh termasuk pembentukan bulu. Protein bulu ayam sekitar $90 \%$ yang merupakan keratin. Protein yang dikonsumsi dimanfaatkan oleh ayam pedaging untuk memenuhi kebutuhan pokok, pertumbuhan jaringan dan pertumbuhan bulu, serta sebagian akan terbuang melalui ekskreta. Bulu berfungsi menjaga suhu tubuh, melindungi dari luka, dan sebagai hiasan. Pertumbuhan bulu ke arah luar dari epidermis akan membentuk bulu penutup tubuh ayam (Suprijatna et al., 2005). Bobot bulu mencapai 4-9\% dari bobot tubuh; tergantung spesies, umur, dan jenis kelamin (Harisshinta, 2009).

\subsection{Berat dan Persentase Berat Kepala Ayam Broiler}

Rata-rata berat kepala ayam broiler dan persentasenya tersaji pada Tabel 2. Rata-rata berat kepala tertinggi adalah pada perlakuan $T_{3}(52,36 \pm 4,13$ g/ekor), diikuti $\mathrm{T}_{0}(48,58 \pm 2,29 \mathrm{~g} / \mathrm{ekor}), \mathrm{T}_{2}(48,48 \pm 8,35 \mathrm{~g} / \mathrm{ekor})$, dan terendah pada $\mathrm{T}_{1}(46,07 \pm 2,83$ g/ekor). Analisis sidik ragam menunjukkan bahwa perlakuan berpengaruh tidak nyata terhadap berat kepala ayam broiler. Ratarata persentase berat kepala tertinggi adalah pada perlakuan $T_{0}$ $2,59 \pm 0,11 \%$ /ekor, diikuti $\mathrm{T}_{3} 2,38 \pm 0,16 \%$ /ekor, $\mathrm{T}_{2} 2,33 \pm 0,34 \% /$ ekor, dan terendah pada $\mathrm{T}_{1} 2,22 \pm 0,15 \% /$ ekor. Hasil penelitian ini menunjukkan bahwa ayam broiler memperlihatkan pertumbuhan atau perkembangan kepala yang sama untuk semua perlakuan. Berat kepala lebih dipengaruhi oleh beberapa faktor yakni genetik, nutrien, jenis kelamin, umur ayam, dan faktor lingkungan (Tumuva dan Teimouri, 2010). Kepala merupakan organ tubuh yang lebih banyak organ tulangnya dari pada dagingnya. Kepala dan leher secara ekonomis memiliki nilai jual rendah dan sering menjadi permasalahan karena kurang diminati. Kepala dan leher biasanya dibuang sebagai limbah atau dikeringkan untuk dijadikan pakan ternak (Dika, 2011).

\section{Simpulan}

Berdasarkan hasil dan pembahasan, dapat disimpulkan bahwa suplementasi dl-methionine sampai $0,70 \%$ dalam pakan $\mathrm{BR}_{1}$ meningkatkan berat potong, berat darah, serta menurunkan berat non karkas dan berat bulu ayam broiler.

\section{Pustaka}

Anggorodi, H. R. 1995. Nutrisi Aneka Ternak Unggas. Gramedia Pustaka Utama, Jakarta.

Amerah, A. M., Gimenez-Rico, R. D., \& Ravindran, V. 2013. Effect of heat stress and betaine source on growth performance and carcass characteristics of broiler chickens fed corn based diets. World's Poultry Science Journal, 69 (Suppl.), 1-3.

Amrullah, I.K. 2004. Nutrisi Ayam Broiler. Lembaga Satu Gunung Budi. Bogor.

Alfi, M. F. 2009. Pengaruh penggunaan tepung roti afkir sebagai pengganti jagung dalam ransum terhadap produksi karkas ayam broiler jantan Skripsi. Fakultas Peternakan, Universitas Diponegoro. Semarang.

Biquili, S. F., E. T. Moran Jr., and N. Car. 1992. Strain cross response of heavy male broilers to dietary enzyme in finisher feed live performance of futher processing yield. Poultry Sci. 16: 177-188.

Conde-Aguilera, J. A., M. A. Aguinaga, L. Lara, J. F. Aguilera, and R. Nieto. 2011. Carcass traits and organ weights of $10-25-\mathrm{kg}$ body weight Iberian pigs fed diets with different protein-toenergy ratio. Anim. Feed Sci. Technol. 164: 116-124.

Dika, M. 2011. Pengaruh perendaman dalam larutan sodium trypolyphospate (na5p3o10) terhadap kadar air, protein, kalsium dan organoleptik keripik leher ayam. Skripsi. Fakultas Peternakan, Universitas Andalas. Padang.

Ensminger, M. E., C. G. Scanes, and G. Brant. 2004. Poultry Scince. 4th Edition. Pearson Prentice Hall, New Jersey.

Harisshinta, R. 2009. Pengaruh penggunaan limbah teh dalam pakan terhadap persentase karkas, lemak abdominal, kandungan lemak daging dan berat organ dalam ayam pedaging. Skripsi. Fakultas Peternakan Universitas Brawijaya, Malang.

Khoiruddin, M. 2009. Pengaruh protein ransum dan periode indukan terhadap bobot badan akhir, bobot karkas, bobot nonkarkas pada ayam broiler. Skripsi. Fakultas Peternakan dan Pertanian Universitas Diponegoro. Semarang.

Kusnadi, E. 2009. Perubahan Malonaldehida Hati, Bobot Relatif Bursa Fabricius dan Rasio Heterofi 1/Limfosit (H/L) Ayam Broiler yang Diberi Cekaman Panas. Media Peternakan, 32(2) : 81-87. 
Lesson, S. and J. D. Summers. 2001. Nutrition of the Chicken. 4th Ed. Ontario, Canada.

Nofal, M. E., Galal, M. A., Mousa, S. M. M., Yassein, D. M. M., \& Bealsh, A. M. A. (2015). Effect of dietary betaine supplementation on productive, physiological and immunological performance and carcass characteristic of growing developed chicks under the condition of heat stress. Egyptian Poultry Science Journal, 5623(35) : 237-259

NRC, 1994. Nutrient Requirements of Poultry. 9th Rev Ed. National Academy Press. Washington DC.

Sakomura, N. K., Barbosa, N. A. A., Longo, F. A., da Silva, E. P., Bonato, M. A., \& Fernandes, J. B. 2013. Effect of dietary betaine supplementation on the performance, carcass yield, and intestinal morphometrics of broilers submitted to heat stress. Revista Brasileira de Ciência Avícola, 15(2) : 105-112.

Soeparno. 2005. Ilmu dan Teknologi Daging Gadjah Mada University Press. Yogyakarta.

Suprijatna, E., U. Atmomarsono, dan R. Kartasudjana. 2005. Ilmu Dasar Ternak Unggas. Penebar Swadaya. Jakarta.

Soepraptini J., K. Widyayanti, dan A. T. S. E. Gestie. 2011. Perubahan bentuk eritrosit pada hapusan darah anjing sebelum dan sesudah penyimpanan dengan menggunakan citrate phosphate dexrtose. Jurnal Ilmiah Kedokteran Hewan, 4(1): 15-18.

Tumuva, E., and A. Teimouri. 2010. Fat deposition in the broiler chicken: A review. Sci. Agric. Biochem. 41:121-128.

Yanti, E. G., Isroli, dan T. H. Suprayogi. 2013. Performans darah kambing peternakan ettawa darah yang diberi ransum dengan tambahan urea yang berbeda. Animal Angricultural Journal, 2(1): 439-444. 